\title{
THE EFFECT OF ACTINOMYCIN D ON THE FIBROBLAST OF THE PULP OF THE RAT INCISOR
}

\section{A STUDY BY QUANTITATIVE RADIOAUTOGRAPHY AND ELECTRON MICROSCOPY}

\author{
S. S. HAN, J. K. AVERY and J. S. BANG
}

Department of Oral Biology, School of Dentistry and Department of Anatomy, School of Medicine, The University of Michigan, Ann Arbor, Michigan 48104, U.S.A.

\begin{abstract}
Summary-The effect of actinomycin D on the fibroblast of the dental pulp of continuously growing rat incisors is studied by means of radioautography and electron microscopy. Results of grain counts of radioautographs at various times following an injection of $\mathrm{H}^{3}$-leucine indicate that there is a progressive decrease in incorporation of the isotope by fibroblasts which reaches a maximum decrease on day 7 and subsequently regenerate to a near normal value by the end of the experiment on day 21 .

Electron microscopic observations of the fine structure of the fibroblast parallel the radioautographic findings in that the maximum degeneration of intracellular structures is observed on day 7 with gradual recovery from that point on. The most seriously affected structures are the rough surfaced endoplasmic reticulum, the Golgi apparatus and the appearance of polyribosomes, the structures that are thought to be directly involved in the elaboration and secretion of proteins. In addition, increased irregularity in size and shape of mitochondria is observed. A large number of lipid droplets as well as cytolysomes appear during the period between 7 and 10 days. The observations on the nucleolus confirm descriptions by previous workers.
\end{abstract}

\section{INTRODUCTION}

As THE successful synthesis of the actinomycin was achieved (BROCKMAN, 1960) and its specific action became clear (GoldRerg and Reich, 1964), numerous biochemical efforts have been made to establish the effect of actinomycin on various species of RNA and protein biosyntheses under different conditions. This antibiotic combines specifically with the guanine portion of the DNA helix resulting in the inhibition of DNA dependent RNA polymerase activities (REICH, 1964). Radioautographic and biochemical studies utilizing actinomycin have shown that all species of cytoplasmic RNA are derived from the nucleus and that the administration of actinomycin D brings forth an inhibition of protein and total RNA syntheses (CASPERSSON et al., 1963; FrankLIN, 1963; LeVY, 1963; TAMAOKI and Mueller, 1962), although there has been some conjecture regarding the resistance of 4s RNA synthesis (FrANKLIN, 1963). Furthermore, degradation of ribosomes by actinomycin has been observed both under in vivo (Staehelin, WeTtSTein and Noll, 1963) and in vitro conditions (WIESNER et al., 1965). As far as the fine structural reflection of these chemical effects is concerned, several workers described rather remarkable nuclear and nucleolar changes following the administration of the antibiotic in a massive dose (GolDSTEIN, SlotNicK and Journey, 1960; JeZequel and Bernard, 1964; Jones and ElsDale, 
1964; JourneY and Goldstein, 1961; SCHOEFL, 1964). Few noted modifications of other cytoplasmic structures, except occasional cytoplasmic blebs observed in $\mathrm{HeLa}$ cells (JOURNEY and GoldSTEIN, 1961). On the other hand, previous light microscopic observations demonstrated that actinomycin D produced profound cytoplasmic changes in cells concerned with protein synthesis (JHEE and HAN, 1964; JHEE, HAN and AVERY, 1965; SMITH, 1966).

In the light of the background stated above, it was thought that a thorough examination of cells actively engaged in protein and nucleic acid syntheses should reveal electron microscopic evidence of detrimental effects of actinomycins on the intracellular machinery for protein synthesis which could be correlated to chemical changes. The purpose of our study was to examine the actinomycin D-induced changes of the active fibroblast as studied by radioautography of $\mathrm{H}^{3}$-leucine incorporation and by electron microscopy.

\section{MATERIALS AND METHODS}

Two independent series of experiments were carried out in the following manner.

\section{Experiment I: radioautography}

Forty-eight young adult male Sprague-Dawley rats were used. The animals were pair fed in three groups of eight pairs each. Experimental animals from all groups were given $0.15 \mu \mathrm{g}$ of actinomycin $\mathrm{D} / \mathrm{g}$ of body weight. The antibiotic was dissolved by adding $2.5 \mathrm{mg}$ of it to $0.25 \mathrm{ml}$ of ethanol which was further diluted to contain $200 \mu \mathrm{g}$ of actinomycin $\mathrm{D} / \mathrm{ml}$ of $0.15 \mathrm{M} \mathrm{NaCl}$. Control rats received an injection of the equivalent amount of $0 \cdot 15 \mathrm{M} \mathrm{NaCl}$. One pair from each group was sacrificed 0 , $1,3,5,7,10,14$ and 21 days after the injection. The animals of Group A were given an intraperitoneal injection of $2.5 \mu \mathrm{c} \mathrm{H}^{3}$-leucine/g of body weight at $10 \mathrm{~min}$ prior to sacrifice, whereas Groups B and C received the isotope injections $30 \mathrm{~min}$ and $4 \mathrm{hr}$ prior to sacrifice respectively.

Following sacrifice the mandibles were dissected out and fixed in Bouin's solution for 2-3 days, decalcified in 10\% formic acid and then double embedded in Paraplast. Longitudinal sections of the incisor teeth were made at $10 \mu$ in thickness and mounted on glass slides. The slides were coated with Kodak NTB-3 liquid emulsion, and kept in a completely sealed slide box containing Drierite at $4^{\circ} \mathrm{C}$ for a period of 2-6 weeks. Radioautographs were developed in Kodak D-19 and tissues were stained with haematoxylin and eosin immediately following the development.

Quantitation of radioautographic grains was made under a $100 \times$ oil immersion lens. Grains overlying the cytoplasm of individual fibroblasts were counted in each animal. At least twenty to thirty cells were counted from midportion of each pulp where mature fibroblasts are concentrated (HAN, AVERY and HALE, 1965).

\section{Experiment II: electron microscopy}

For this series the same regimen used in the first experiment was used. Three pairs of rats were sacrificed for each interval and pulp tissues prepared for electron microscopy as described in the following. 
While the rats were under ether anesthesia, pulp tissues for electron microscopy were taken out. One-half of the mandible was rapidly dissected and, using a pair of shears, the body of the mandible was clipped off along the lateral aspect of the base from the angle forward and the entire incisor was exposed. Then, the tooth was removed from the mandible and briefly dipped in the fixative. The partially calcified dentine from the proximal portion was separated from the pulp, which in turn was removed from the hard shell of dentine by gently pulling with jeweller's forceps. The midportion of the pulp was cut into small pieces approximately $1 \mathrm{~mm}^{3}$ in size and fixed for $2 \mathrm{hr}$ in either $2 \% \mathrm{OsO}_{4}$ in $0 \cdot 1 \mathrm{M}$ phosphate buffer with $4 \%$ sucrose at $\mathrm{pH} 7.4$ or in $2 \%$ glutaraldehyde in the same buffer. The ones fixed in glutaraldehyde were postfixed with $2 \% \mathrm{OsO}_{4}$ for a period of up to $2 \mathrm{hr}$. The tissues were briefly rinsed in the buffer, dehydrated and embedded in a mixture of Epon in a routine manner. Ultrathin sections were made on a LKB ultramicrotome, stained with $0.1 \%$ aqueous phosphotungstic acid and saturated uranyl nitrate for variable lengths of time. Observations were made in a Hitachi HU-11 electron microscope.

\section{Radioautography}

\section{RESULTS AND OBSERVATIONS}

Figures 1-3 summarize the results of grain counts made in each animal. Each point represents a mean grain number of twenty to thirty cells with the highest and lowest counts indicated by the vertical bar. It may be noted that a moderate number of

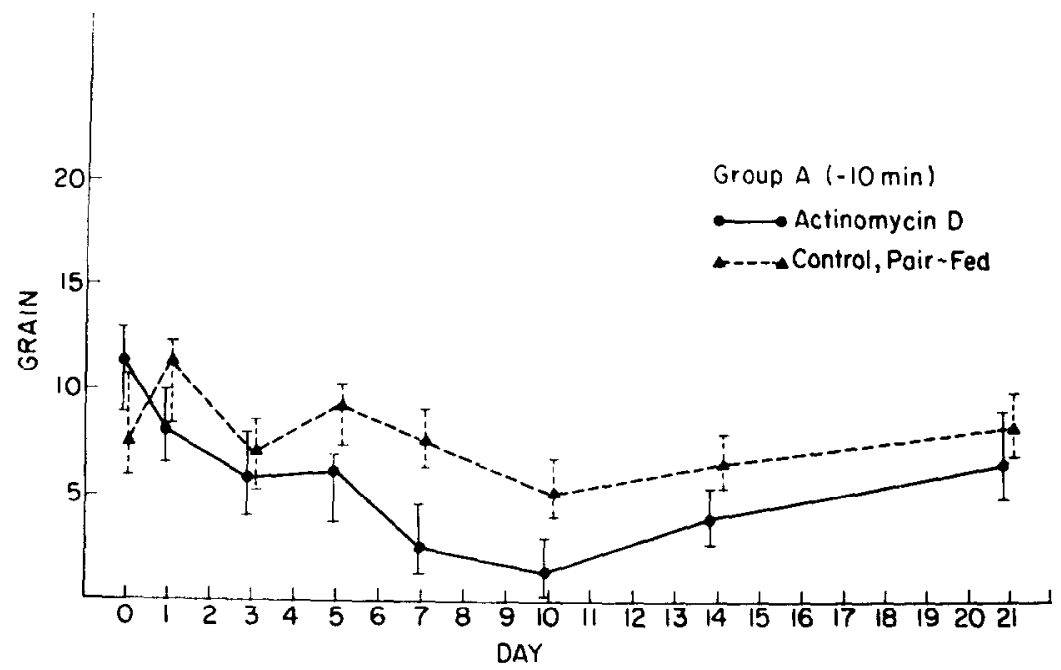

FIG. 1. A comparison of average number of grains per fibroblast between experimental and control animals injected with $\mathrm{H}^{3}$-leucine, $10 \mathrm{~min}$ prior to sacrifice. The grain number drops gradually throughout the first 10 days, which shows a tendency of recovery afterwards. A clear difference in grain numbers between experimental and control rats are seen by 3 days after injection. The decreases of grain numbers observed in the control may reflect the necessary restriction of their food intake due to pair feeding. 


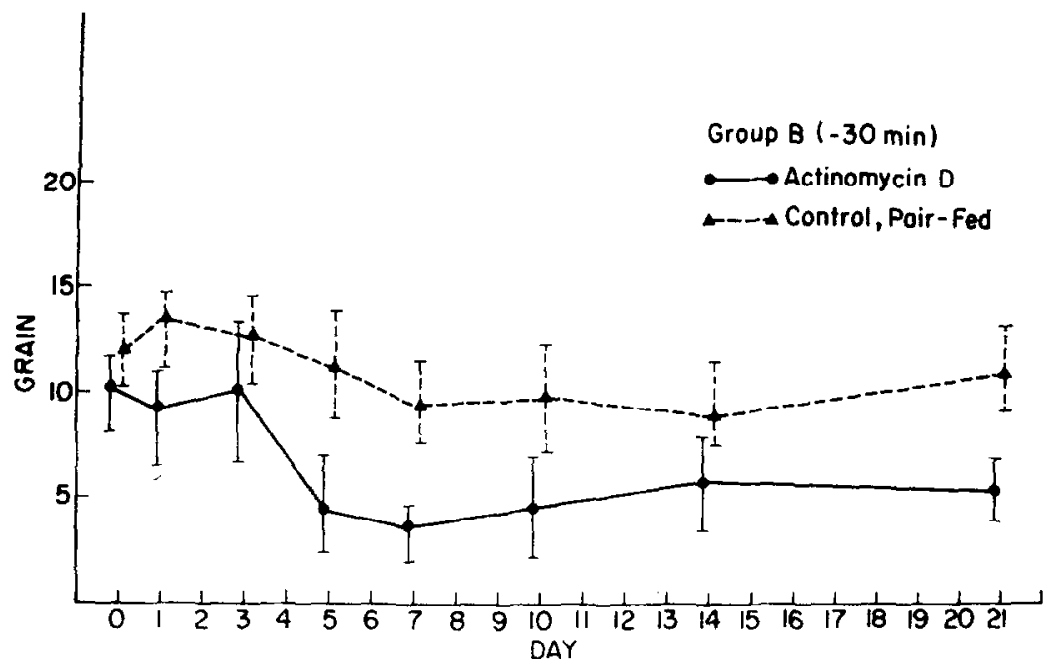

FIG. 2. A comparison of average grain number per fibroblast between experimental and control animals injected with $\mathrm{H}^{3}$-leucine, $30 \mathrm{~min}$ prior to sacrifice. Essentially a similar picture is observed as in Group A, except that the difference between the control and actinomycin $\mathrm{D}$ injected animals is more evident.

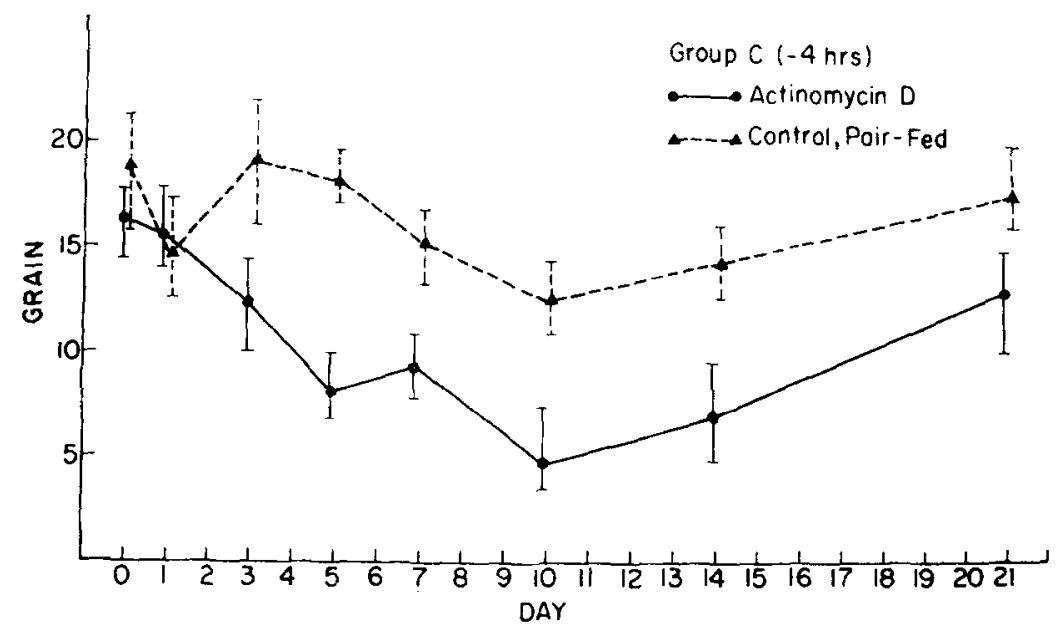

Fig. 3. A comparison of average number of grains per fibroblast between experimental and control animals injected with $\mathrm{H}^{8}$-leucine, $4 \mathrm{hr}$ prior to sacrifice. A greater difference between the two groups is noted. The consistent separation of grain counts after day 3 and on indicates a definite damage has been made by that time.

grains was observed as early as 10 min after the injection of $\mathrm{H}^{3}$-leucine and the number increased considerably by $30 \mathrm{~min}$. By $4 \mathrm{hr}$ after injection a generally higher value was obtained over the 30-min value. In experimental animals fewer grains were observed 
throughout the first 10 days and, during 14-21 days, there was a significant increase in number of grains, especially of experimental animals. The decrease of grain numbers of control rats during days 7 and 10 probably reflects the relatively reduced food intake allowed because of the pair-feeding. It was also of interest to note that the difference between control and experimental animals was more evident in animals that were sacrificed at a longer time after injection of $\mathrm{H}^{3}$-leucine (Group C).

Insofar as the pattern of distribution of the tracer was concerned there was an indication that in the control animals at 10 and $30 \mathrm{~min}$ after injection the grains were more or less uniformly distributed throughout the cytoplasm whereas they tended to concentrate more in the small juxtanuclear region at $4 \mathrm{hr}$ after the injection. However, this observation was nowhere as clear-cut as could be observed in more polarized secretory cells such as exocrine pancreas (WARSHAWSKY, LEBLOND and DROZ, 1963).

\section{Electron microscopy}

Numerous original and review articles are available for the description of the fine structure of fibroblasts from normal animals (CHAPMAN, 1962; HAN et al., 1965; PORTER, 1964). Therefore the following summary of observation is given in lieu of illustrating the fine structure of fibroblasts from control animals.

In the fairly large stellate-shaped cell body the fibroblast had a cytoplasm which was endowed with a well-developed rough-surfaced endoplasmic reticulum (RER), containing materials of a moderate but variable electron density. The Golgi complex was also extensively developed occupying a juxtanuclear position. It was composed of several stacks of flattened sacs, small and large vesicles, and vacuoles which seemed to communicate with the membranous portion of the complex as well as the RER. In the vicinity of Golgi apparatus was located a number of dense dark bodies which resembled small lysosomes. Throughout the cytoplasm filamentous to rod-shaped mitochondria with fairly well developed cristae were distributed. The nucleus of the cell was usually ovoid having a prominent nucleolus.

Modifications of structural machinery responsible for protein synthesis in experimental animals. A limited distortion of the intracytoplasmic structures was observed 1 day after the injection of actinomycin $D$ and reached a maximum degree of degeneration between 7 and 10 days after the injection. The illustrations included in this article will primarily represent some of the more dramatic changes observed during this period. The most seriously affected of the intracellular structures were those regarded to be responsible for the synthesis of intercellular matrix, namely the RER and the Golgi complex. Other cytoplasmic features including mitochondria appeared to be moderately affected (Figs. 6 and 8 ).

The usually flat profiles of the RER became dilated in most cells and showed a partial loss of the ribosomes (Figs. 4, 7 and 8). Sometimes such dilated profiles showed no ribosomes (Fig. 7). The interior of the RER contained relatively less electron dense materials but occasionally clumps of what appeared to be membranous debris were seen. In association with the dilatation and the pronounced irregularity of the RER, similar changes were observed in the appearance of the outer nuclear membrane. In certain areas the contour of the outer nuclear membrane became quite irregular, 
showing again a partial loss of ribosomes from it (Fig. 4). The Golgi complex of the fibroblasts from experimental groups (Fig. 6) was definitely of smaller size and less developed than in controls (Fig. 5). Characteristically it was devoid of the extensive lamellated elements and the number of small vesicles was noticeably decreased. Compared to controls the interior of the Golgi membranes was relatively electron-lucent. Few vesicles appeared to be communicating with the RER or the lamellated portion of the Golgi apparatus.

The total number of free ribosomes per unit area was definitely decreased by the end of 1 week. However, a fair number of them formed aggregates, indistinguishable in appearance from polysomes in the normal cells (Fig. 8). Occasionally, large abnormal aggregates composed of a few to several dozen monosomes were seen (Fig. 7). From day 10 and on an increase in number of free ribosomes, especially of polysomes, was observed (Fig. 9). The ribosomal recovery seemed to precede restoration of other cytoplasmic damage such as dilatation of the RER and mitochondrial irregularities.

Changes of other cytoplasmic structures. A rather striking variation was observed in the fine structure of mitochondria present in cells of the experimental group. Although there were some mitochondria which maintained their elongate rod-shaped appearance, many of them appeared to shorten and became rounded (Fig. 10). Frequently invaginations or evaginating blebs were formed by dilatation by the mitochondrial membrane (Fig. 9). When such dilatation was extensive the mitochondrial matrix in that dilated portion was completely electron-lucent with concomitant loss of internal limiting membrane (Fig. 8). The contour of the mitochondrial surface often was irregular. Another change observed in the mitochondrial structure was a notable variation in size of the organelle. Figure 10 illustrates a region in which two adjoining cytoplasmic processes contain mitochondria of considerably different sizes.

Elsewhere in the cell were present masses of cytoplasmic structures containing small profiles of the RER, ribosomes and mitochondria. Such masses were segregated by a membrane, exhibiting areas of increased density of their content (Fig. 11), and resembled cytolysomes. In addition, many lipid droplets appeared towards the end of the first week in the cytoplasm of the fibroblast (Figs. 12 and 13). They were so identified on the basis of their typical contour and high electron density of their interior, as well as the close correlation between electron micrographs and fresh tissue sections stained with Sudan black B.

The nucleoplasm remained relatively unchanged. However, a drastic decrease was noted in the size of the nucleoli which appeared as a few peripheral clumps of dense matrix surrounding a less dense portion (Figs. 14 and 15 ). The $150 \AA$-granules, which usually were present at the periphery forming a zone of variable widths, were sharply reduced in number. Often the dense nucleolar core was completely denuded of the granules.

\section{DISCUSSION}

Although an accurate estimate of the changes in the rate of $\mathbf{H}^{3}$-leucine incorporation cannot be assessed without a knowledge of the total intracellular pool size of hot and cold precursor molecules under study, the results from our radioautographic 
study support those of previous biochemical reports (STAEHELIN et al., 1963; WIESNER et al., 1965) and indicate that there is a significant reduction of $\mathrm{H}^{3}$-leucine incorporation as evidenced by grain counts. By entirely different quantitative cytochemical methods CASPERSSON et al. (1963) have demonstrated the parallelism between actinomycin D-induced inhibition of protein synthesis and that of RNA synthesis.

Contrary to previous statements that no cytoplasmic changes were observed in actinomycin treated cells in vivo (JEZEQUEL and BERNHARD, 1964), our observations clearly demonstrate the detrimental effects of actinomycin D on morphological units of protein synthesis and other organelles which are presumed to be metabolically related to the synthesis of protein. It is probable that some of the secondary changes such as lipid droplet formation and mitochondrial alteration may not have been visualized in previous experiments in which events immediately after injection of a massive dose were studied. However, the fact that most biochemical endeavours have shown a rapid breakdown of polysomes (STAEHELIN et al., 1963; WiESNER et al., 1965) speaks for possible structural changes on polysomes and RER, which are evident in our micrographs.

It is significant that the greatest reduction in the number of individual ribosomes and disorganization of the RER was present after 7 days of injection when the grain count was approaching the lowest point. The disruption of the profiles of the RER along with the reduction in electron density of its content during this time also suggest the possibility that the RER might not be functioning normally and that it might contain only a limited amount of secretory materials. The formation of vacuoles by the RER may represent a relatively non-specific response of the membrane system which is related also to other degenerative processes of the intracytoplasmic structure (Herman and Fitzgerald, 1962; Weishlum, Herman and Fitzgerald, 1962).

Of interest is the persistance of polyribosomes present in fair number even during the period when the cells are most seriously affected. This could mean one or both of the following two possibilities: (1) There could be a limited synthesis of mRNA under the experimental conditions. (2) In the absence of mRNA synthesis there could be a certain amount of mRNA which have a longer life span that might be responsible for the continuous appearance of polyribosomes. Since there is no available information regarding the degree of inhibition of mRNA synthesis in fibroblasts with the dose used, a definite conclusion cannot be drawn as to which of the above possibilities is operative. Biochemically it has been shown that a complete breakdown of polysomes is difficult to achieve even with a very large dose of actinomycin. Thus StaEHELIN $e t$ al. (1963) have indicated that $50-80$ per cent of ribosome-associated mRNA in liver cells breaks down within 4-8 hr after actinomycin doses that are expected to inhibit mRNA synthesis almost completely. Also recent works by WIESNER et al. (1965) have shown that in monolayer culture of mouse fibroblasts (L-929) approximately 40-70 per cent of original RNA is degraded with $1 \mu \mathrm{g}$ of actinomycin $\mathrm{D}$ per $\mathrm{ml}$ of culture fluid. Upon analysis it was found that all species of RNA including ribosomal RNA were degraded. They have also demonstrated that "young" RNA were relatively more susceptible to the antibiotics than "old" molecules and that the latter represented the persisting RNA. In any case, it is not strange to 
see polysomes in the electron micrographs, since radioautographic grain patterns of this study indicates a reduced but persistant incorporation of $\mathrm{H}^{3}$-leucine throughout the experiment.

Alterations in the mitochondrial shape and size can be taken as indicative of disturbance in energy metabolism and therefore might be regarded as one of secondary changes related to reduced synthesis of proteins. The increase in number of cytolysomes is of interest and may reflect the increased lysosomal activities as evidenced by histochemical studies (SzaKal and HaN, 1966). The appearance of numerous fat droplets present in so many cells might also reflect the disturbed relationship between protein and lipid metabolism as has been shown in other studies (Ross and BENDITT, 1965). Despite the evidence that the Golgi apparatus may not be responsible as the sole organelle concerned with the condensation and final release of secretory material in the fibroblast (HAN et al., 1965; Ross and BENDITT, 1965), the general reduction in the degree of organization and size of the Golgi complex indicates the importance of this organelle in the performance of secretory activities by the fibroblasts.

While our study shows a definite reduction in the size of nucleoli and a segregation of various morphological components of the nucleoli as has been described by others (Granboulan and Granboulan, 1964; Jezequel and Bernhard, 1864; Schoefl, 1964), the degree to which these changes occurred was less than has been published in the past and perhaps represents differences in the relative sensitivity of cells and/or the amount of actinomycin $\mathrm{D}$ used. In view of the recent claims that nucleoli may be concerned with synthesis and storage of RNA (BusCH et al., 1963; PERRY, HeLl and ERRERA, 1961) and that the $150 \AA$-granules in the nucleolus are ribonuclease-sensitive (SCHOEFL, 1964), the reduction of the ribosome-like granules from the nucleoli at the time when cytoplasmic ribosomes are affected is significant.

Acknowledgements - This work was supported in part by grants from National Institutes of Health (DE-1620) and American Cancer Society (IN 40F).

\begin{abstract}
Résumé-L'effet de l'actinomycine D sur le fibroblaste de la pulpe dentaire de l'incisive de rat, à accroissement continu, est étudié à l'aide de la radio-autographie et de la microscopie électronique. Les résultats du dénombrement des grains sur les radioautographies réalisées, après divers intervalles succèdant à l'injection de leucine $\mathbf{H}^{\mathbf{s}}$, indiquent qu'il y a une décroissance progressive dans l'incorporation de l'isotope dans le fibroblaste: une décroissance maximale est atteinte le 7ème jour et une valeur normale est atteinte à nouveau vers le 21 ème jour.

L'examen au microscope électronique de l'ultrastructure du fibroblaste se recoupe avec les résultats auto-radiographiques, en ce sens que la dégénérescence maximale des structures intracellulaires est observée au 7ème jour: elle est suivie d'une phase de réparation. La structure la plus affectée est l'ergastoplasme, l'appareil de Golgi et l'appariton de polyribosomes, lesquels sont considérés comme étant directement liés à l'élaboration et la sécrétion des protéines. De plus, une augmentation de l'irrégularité de taille et de forme des mitochondries est observée. Un grand nombre de gouttelettes lipidiques et de cytolysomes sont visibles entre le 7ème et le 10ème jour. La structure des nucléoles est conforme aux descriptions antérieures.
\end{abstract}

\footnotetext{
Zusammenfassung-Mit Hilfe der Radioautographie und der Elektronenmikroskopie wurde die Wirkung von Aktinomycin D auf den Fibroblasten der Zahnpulpa des ständig wachsenden Rattenschneidezahnes untersucht. Die Ergebnisse der Kornzählungen von
} 
Radioautographien zu verschiedenen Zeiten nach Injektion von $\mathbf{H}^{\mathbf{8}-L e u c i n}$ zeigt, daß es einen progressiven Abfall der Inkorporation des Isotops durch die Fibroblasten gibt; dieser Abfall ist am 7. Tage am ausgeprägtesten und et nähert sich gegen Ende des Experiments am 21. Tage wieder dem Normalwert.

Elektronenmikroskopische Beobachtungen an der Feinstruktur des Fibroblasten kommen den radioautographischen Befunden insoweit gleich, als die stärkste Degeneration der intrazellulären Strukturen am 7. Tage mit nachfolgender gradueller Erholung beobachtet wird. Die am schwersten beeinträchtigten Strukturen sind das rauhflächige endoplasmatische Retikulum, der Golgi-Apparat und das Erscheinen von Polyribosomen, Strukturen, von denen man annimmt, daß sie direkt an der Entwicklung und Sekretion von Proteinen beteiligt sind. Außerdem wird eine gesteigerte Irregularität hinsichtlich Umfang und Form der Mitochondrien beobachtet. Während des Zeitraumes zwischen 7 und 10 Tagen erscheint eine große Anzahl Lopoidtröpfchen wie auch Zytolysome. Die Beobachtungen am Nukleolus bestätigen die Beschreibungen früherer Autoren.

\section{REFERENCES}

Brockman, H. 1960. Die Actinomycine. Fortschr. Chem. Org. NatStoffe 18, 1-54.

Busch, H. Muramatsu, M., Adams, H., Steele, W. J., Liau, M. C. and Smetana, K. 1963. Isolation of nucleoli. Expl Cell Res. (Suppl.) 9, 150-163.

Caspersson, T., Farber, S., Foley, G. E. and Killander, D. 1963. Cytochemical observations on the nucleolus-ribosome system. Effects of actinomycin D and nitrogen mustard. Expl Cell Res. 32, 529-552.

Chapman, J. A. 1962. Fibroblasts and collagen. Br. Med. Bull. 18, 233-237.

Frankin, R. M. 1963. The inhibition of ribonucleic acid synthesis in mammalian cells by actinomycin D. Biochim. biophys. Acta 72, 555-565.

GOLDBERG, I. H. and ReICH, E. 1964. Actinomycin inhibition of RNA synthesis directed by DNA. Fedn Proc. 23, 958-964.

Goldstein, M. N. Slotnick, I. J. and Journey, L. J. 1960. In vitro studies with HeLa cell lines sensitive and resistant to actinomycin. Ann. N.Y. Acad. Sci. 89, 474-483.

Granboulan, N. and Granboulan, P. 1964. Cytochimie ultrastructurale du nucleole. Mise en evidence de chromatine a l'interieur du nucleole. Expl Cell Res. 34, 71-87.

HaN, S. S., AVERY, J. K. and HALe, L. E. 1965. The fine structure of differentiating fibroblasts in the incisor pulp of the guinea pig. Anat. Res. 153, 187-210.

HeRmaN, L. and FItzGerald, P. J. 1962. The degenerative changes in pancreatic acinar cells caused by DL-ethionine. J. Cell Biol. 12, 277-296.

Jezequel, A. M. and Bernhard, W. 1964. Modifications ultrastructurales du pancreas exocrine de rat sous l'effet de l'actinomycine D. J. Microscopie 3, 279-296.

JHEE, H. T. and HAN, S. S. 1964. Effects of actinomycin D on the salivary glands of the rat. Life Sci. $3,1239-1247$.

JHEe, H. T., HAN, S. S. and AVERY, J. K. 1965. A study of salivary glands of rats injected with actinomycin D. Am. J. Anat. 116, 631-652.

JoNES, K. W. and ElsDale, T. R. 1964. The effects of actinomycin D on the ultrastructure of the nucleus of the amphibian embryonic cell. J. Cell Biol. 21, 245-252.

JOURNEY, L. J. and GoldsteIN, M. N. 1961. Electron microscope studies of HeLa cell lines sensitive and resistant to actinomycin D. Cancer Res. 21, 929-932.

Levy, H. B. 1963. Effect of actinomycin D on HeLa cell nuclear RNA metabolism. Proc. Soc. exp. Biol. Med. 113, 886-889.

MERITs, I. 1963. Actinomycin inhibition of RNA synthesis in rat liver. Biochem. biophys. Res. Commun. 10, 254-259.

Perry, R. P., Hell, A. and Errera, M. 1961. The role of nucleolus in ribonucleic acid and protein synthesis. Biochim. biophys. Acta 49, 47.

PORTER, K. R. 1964. Cell fine structure and biosynthesis of intercellular macromolecules. In: Connective Tissue: Intercellular Macromolecules, pp. 167-196. Little, Brown, Boston.

REICH, E. 1964. Actinomycin: Correlation of structure and function of its complex with purines and DNA. Science, N.Y. 143, 684-689. 
Ross, R. and Bendirt, E. P. 1965. Wound healing and collagen formation. V. Quantitative electron microscope radioautographic observations of proline- $\mathrm{H}^{3}$ utilization by fibroblasts. J. Cell Biol. 27, 83-106.

SchoEFL, G. E. 1964. The effect of actinomycin D on the fine structure of the nucleolus. J. Ultrastruct. Res. 10, 224-243.

SMITH, F. N. 1966. The effect of actinomycin D on leucine- $\mathrm{H}^{\mathrm{a}}$ incorporation by odontoblasts and ameloblasts. J. dent. Res. In press.

Staehelin, T., Wettstein, F. O. and Noll, H. 1963. Breakdown of rat-liver ergasomes in vivo after actinomycin inhibition of messenger RNA synthesis. Science, N.Y. 140, 180-183.

SzAKal, A. K. and HAN, S. S. 1967. Histochemical studies of pulpal fibroblasts of rats following actinomycin D administration. Archs oral Biol. 12, 265-274.

TAMAOKI, T. and Mueller, G. E. 1962. Synthesis of nuclear and cytoplasmic RNA of HeLa cells and the effect of actinomycin D. Biochem. biophys. Res. Commun. 9, 451-454.

Terzakis, J. A. 1965. The nucleolar channel system of human endometrium. J. Cell. Biol. 27, 293-304.

Warshawsky, H., Leblond, C. P. and Droz, B. 1963. Synthesis and migration of proteins in the cells of the exocrine pancreas as revealed by specific activity determination from radioautographs. J. Cell Biol. 16, 1-21.

WIESNER, R., ACs, G., ReICH, E. and ShAFIQ, A. 1965. Degradation of ribonucleic acid in mouse fibroblasts treated with actinomycin. J. Cell Biol. 27, 47-52. 


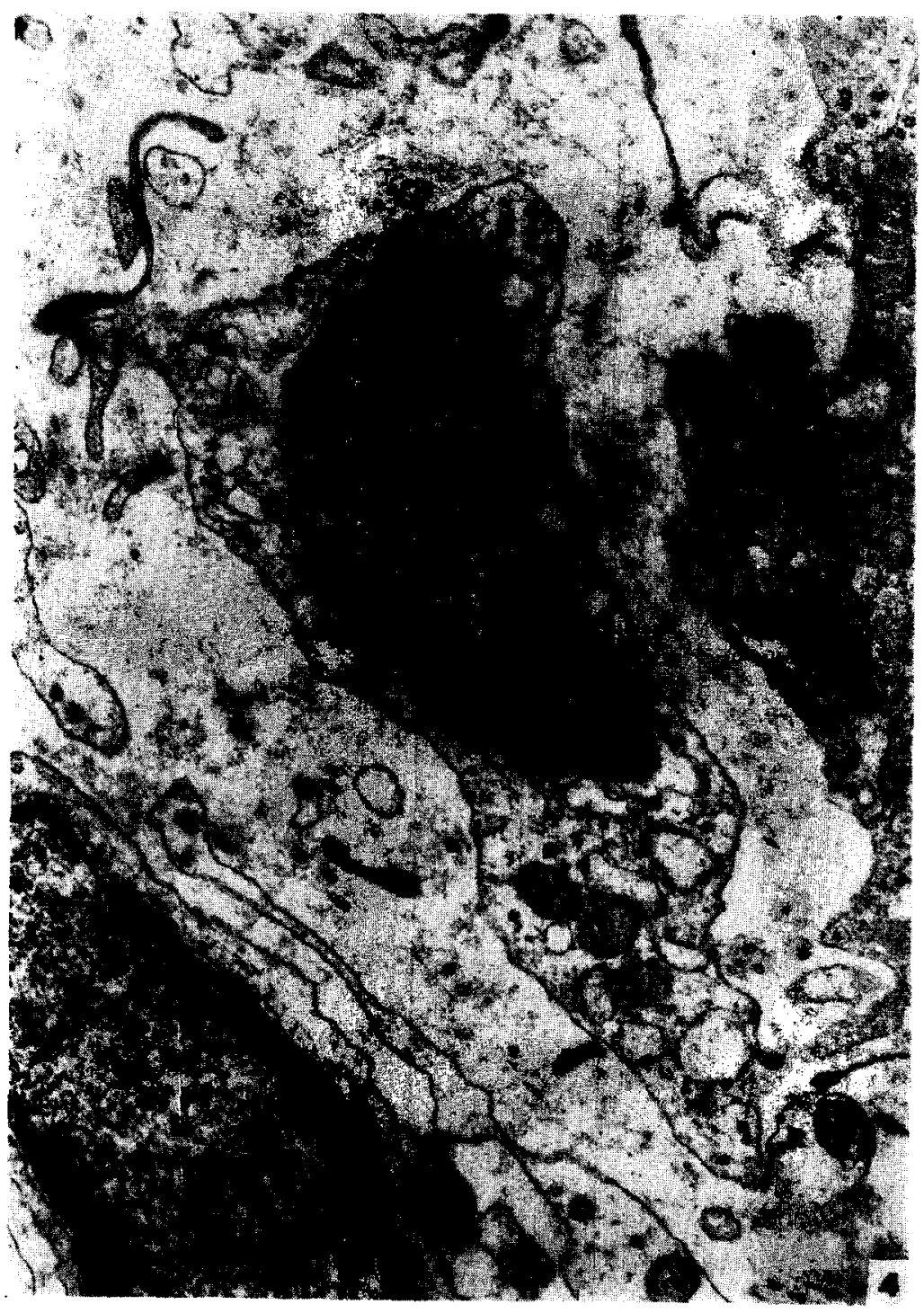

FIG. 4. A low magnification electron micrograph of a fibroblast from an animal injected with actinomycin D, 7 days previously. Notice the dilated profiles of the RER along with irregularities of the outer nuclear membrane. Approximately $\times 9090$. 


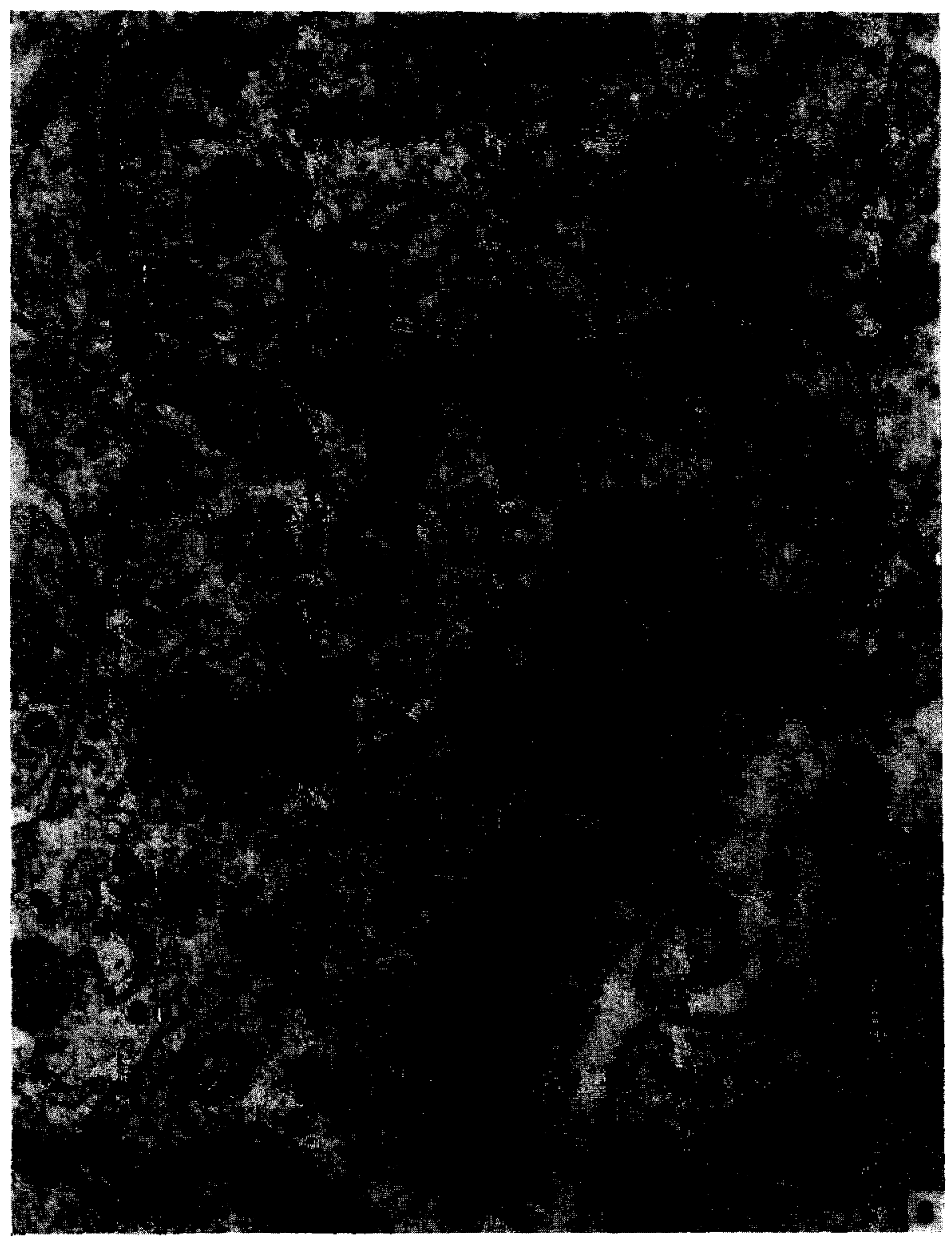

FtG. 5. A portion of a fibroblast from a control animal. Next to the nucleus is a rather well-developed element of the Golgi apparatus which shows some of the vesicular elements making communication with the RER, as well as with the flattened membranes of the complex. In the upper portion of this micrograph are profiles of the extensively developed RER which contain materials of moderate electron density. The nucleus is seen on the lower left hand corner. Approximately $\times 21,000$. 


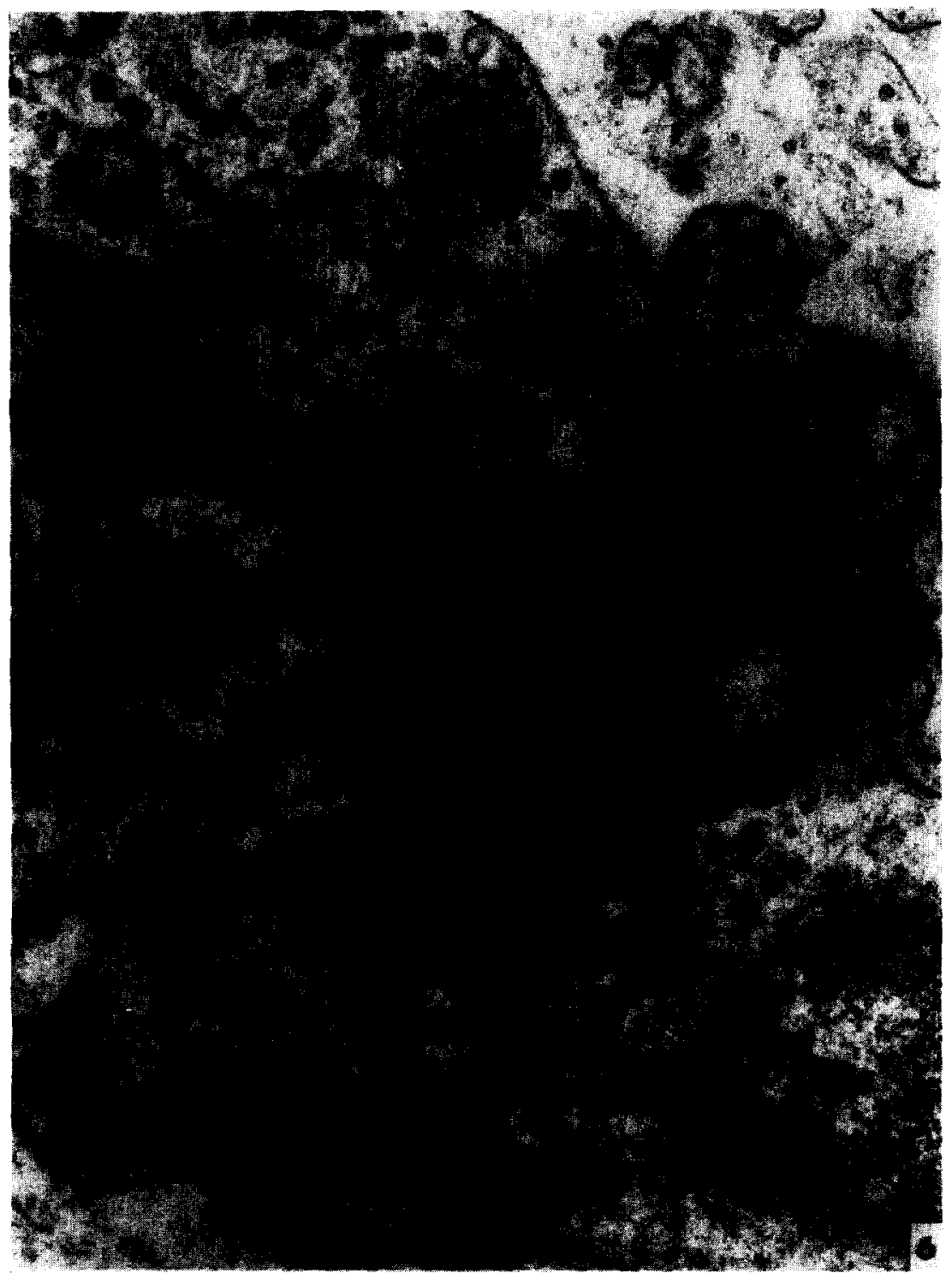

FIG. 6. A Golgi region of a fibroblast from an animal injected with actinomycin D, 7 days previously. Although this particular photograph shows one of the better developed Golgi apparatus found in cells of the experimental animals, the stacks of flattened membranes are mostly gone and the vesicles are of somewhat irregular size and decreased in number. Notice also a few dilated profiles of the RER which show an interior as electron-lucent as the ground cytoplasm of the cell. An obliquely sectioned ciliary shaft is observed (arrow). The nucleus is seen on the lower right hand corner. Approximately $\times 30,850$. 


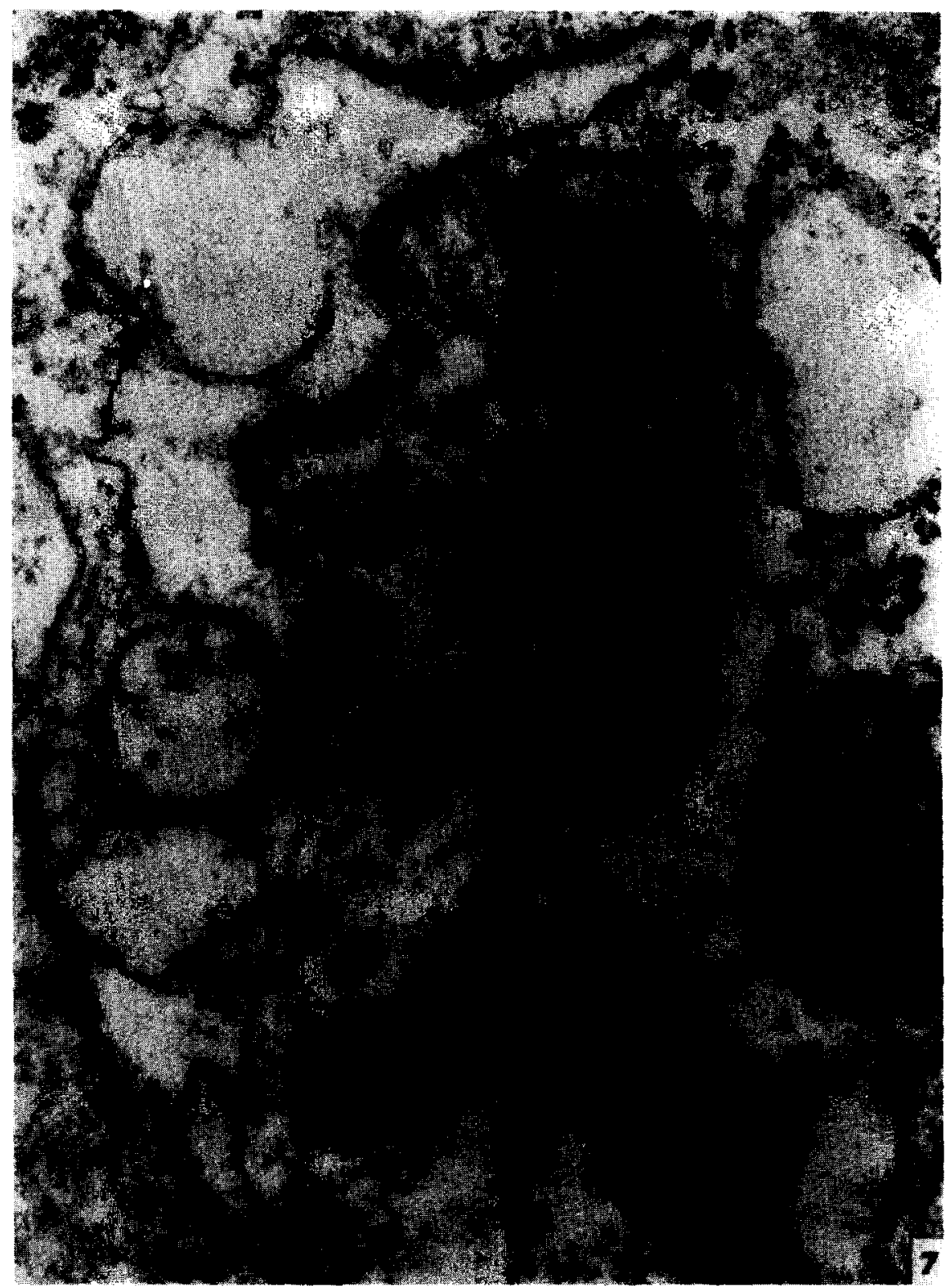

FIG. 7. A portion of cytoplasm of a fibroblast from an experimental animal injected with actinomycin $\mathrm{D}, 7$ days prior to sacrifice. The photograph illustrates the extensive damage done to the appearance of the RER. Notice the partially dilated RER. Elsewhere in the cytoplasm are aggregates of ribosomes, some of which are unusually large. Approximately $\times 65,800$. 


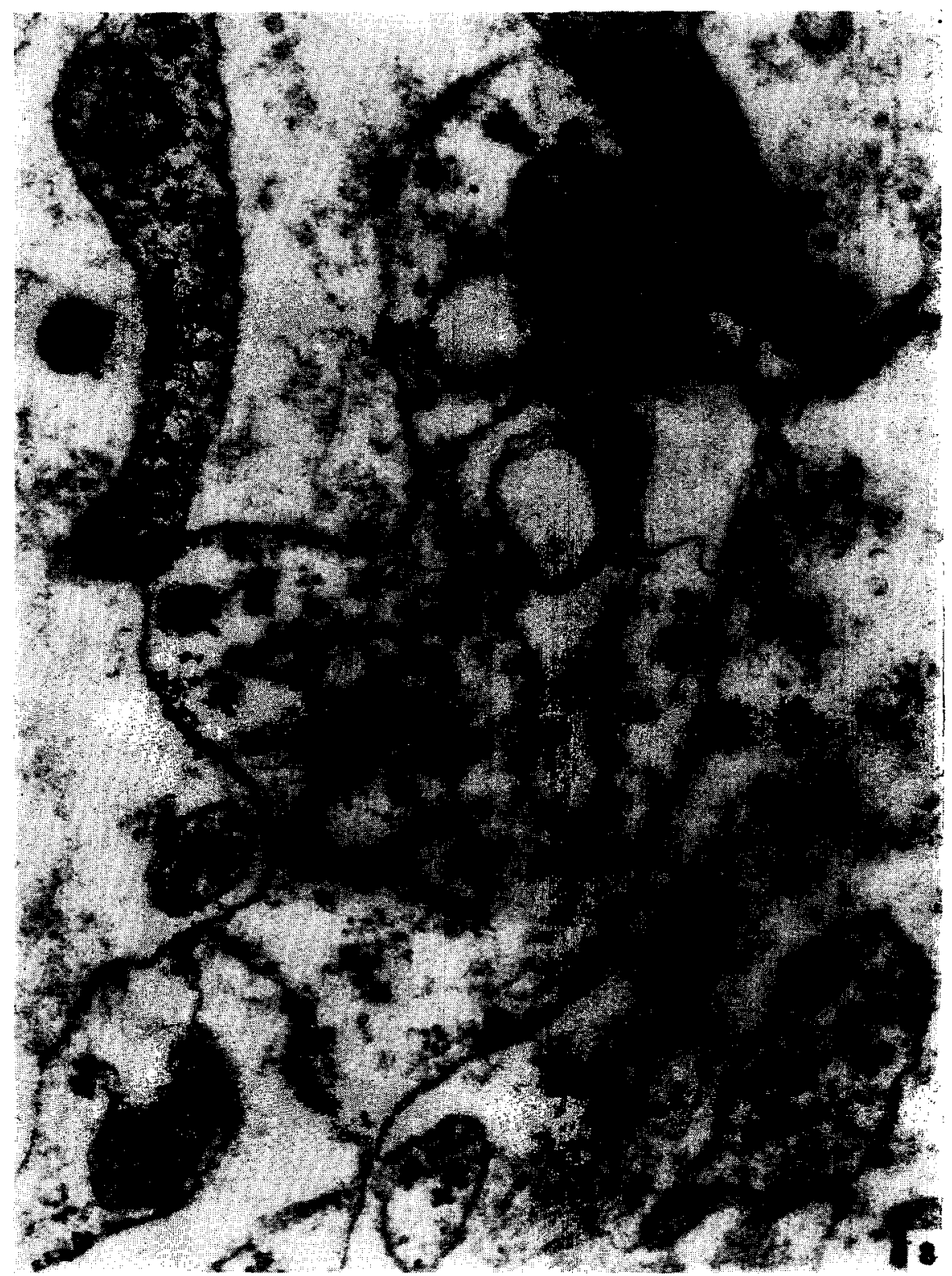

Fig. 8. A portion of peripheral cytoplasm of a fibroblast from an animal injected with actinomycin D, 7 days previously. Notice again the dilatation of the RER and very electron-lucent ground cytoplasm of the cell. The outer limiting membrane of the mitochondria are swollen. Approximately $\times 56,700$. 
S. S. HAN, J. K. Avery AND J. S. Bang

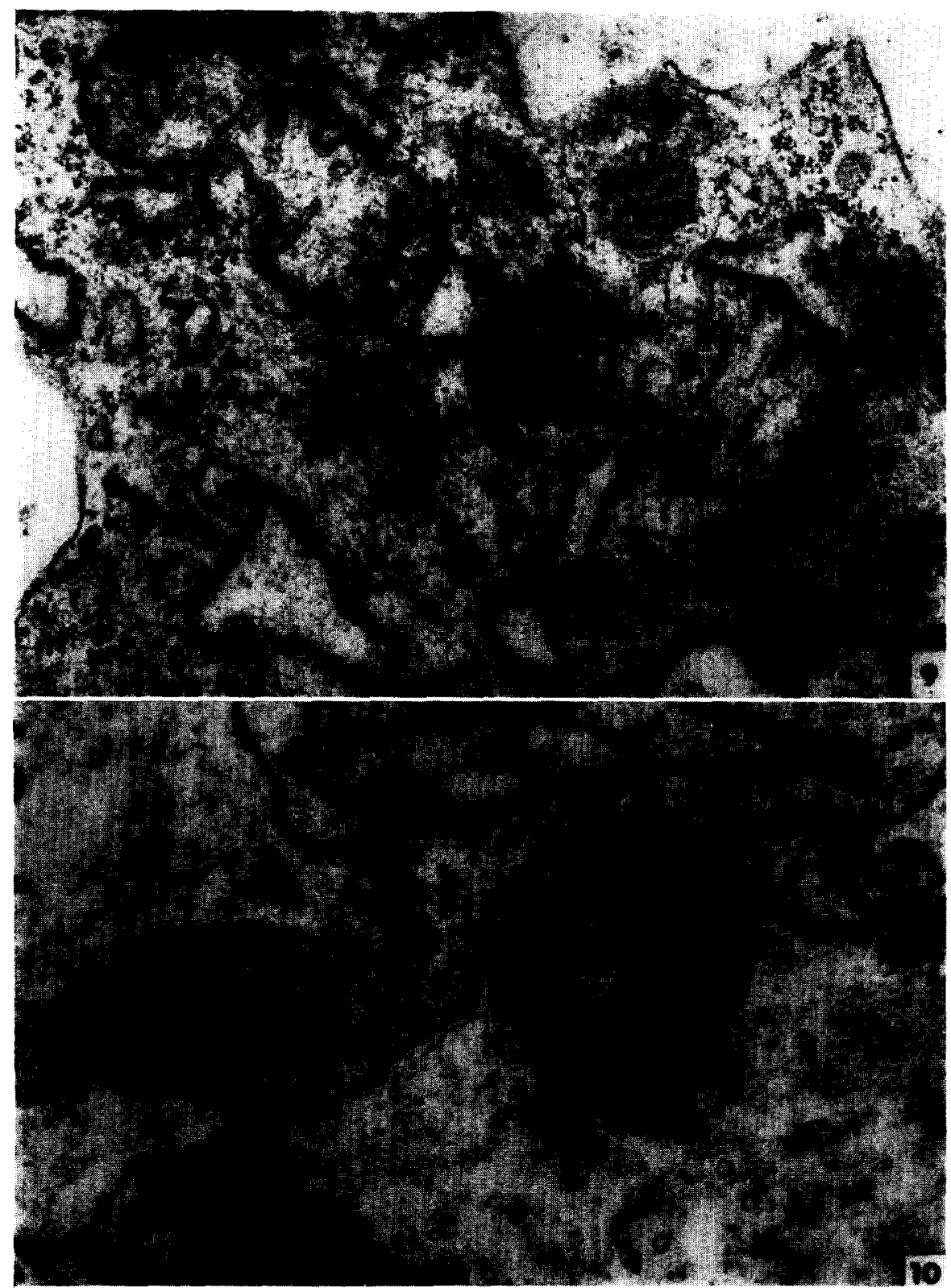

FIG. 9. A portion of a fibroblast cytoplasm from an animal injected with actinomycin D, 10 days previously. Notice the irregularities of the mitochondrial membranes. Several profiles of the RER that have restored their normal appearance may be seen. Also the number of free and aggregated ribosomes has increased considerably compared to the cells depicted in previous figures. Approximately $\times 37,250$.

Fig. 10. Profiles of a few peripheral cyloplasmic processes of fibroblasts from an animal injected with actinomycin D, 2 days previously. Notice that the cytoplasmic processes in these cells do not contain any RER and the size of the mitochondria present in adjacent processes are greatly variable. Approximately $\times 25,340$. 


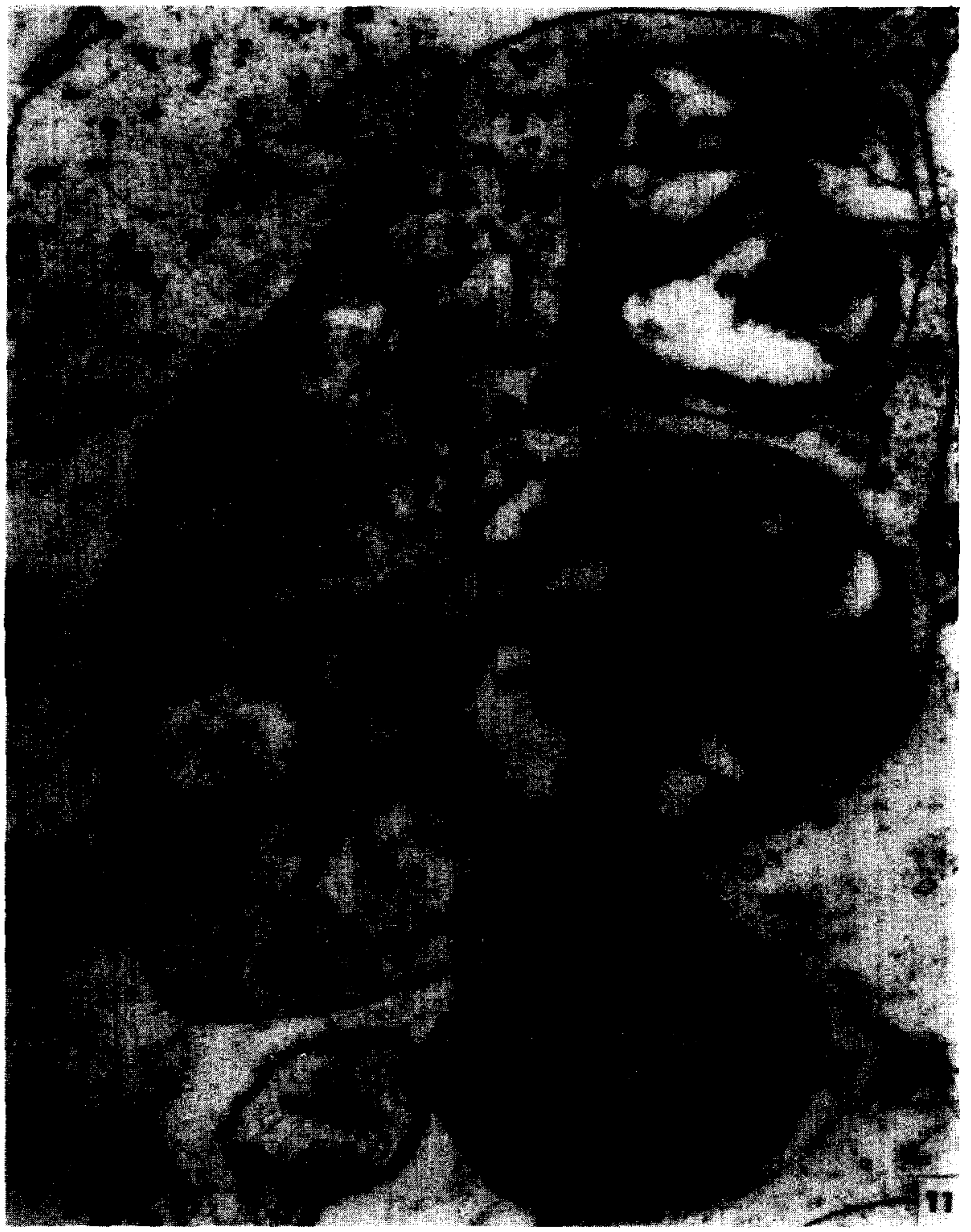

Fig. 11. A portion of peripheral cytoplasm of a fibroblast from a rat injected with actinomycin D, 7 days previously. Notice the appearance of 2 large cytoplasmic bodies containing what can be recognized as RER membranes and free ribosomes. These cytoplasmic bodies appear in increasing number paralleling the increase in acid phosphatase activity of the cell, and may be considered as cytolysomes. Approximately $\times 25,170$. 

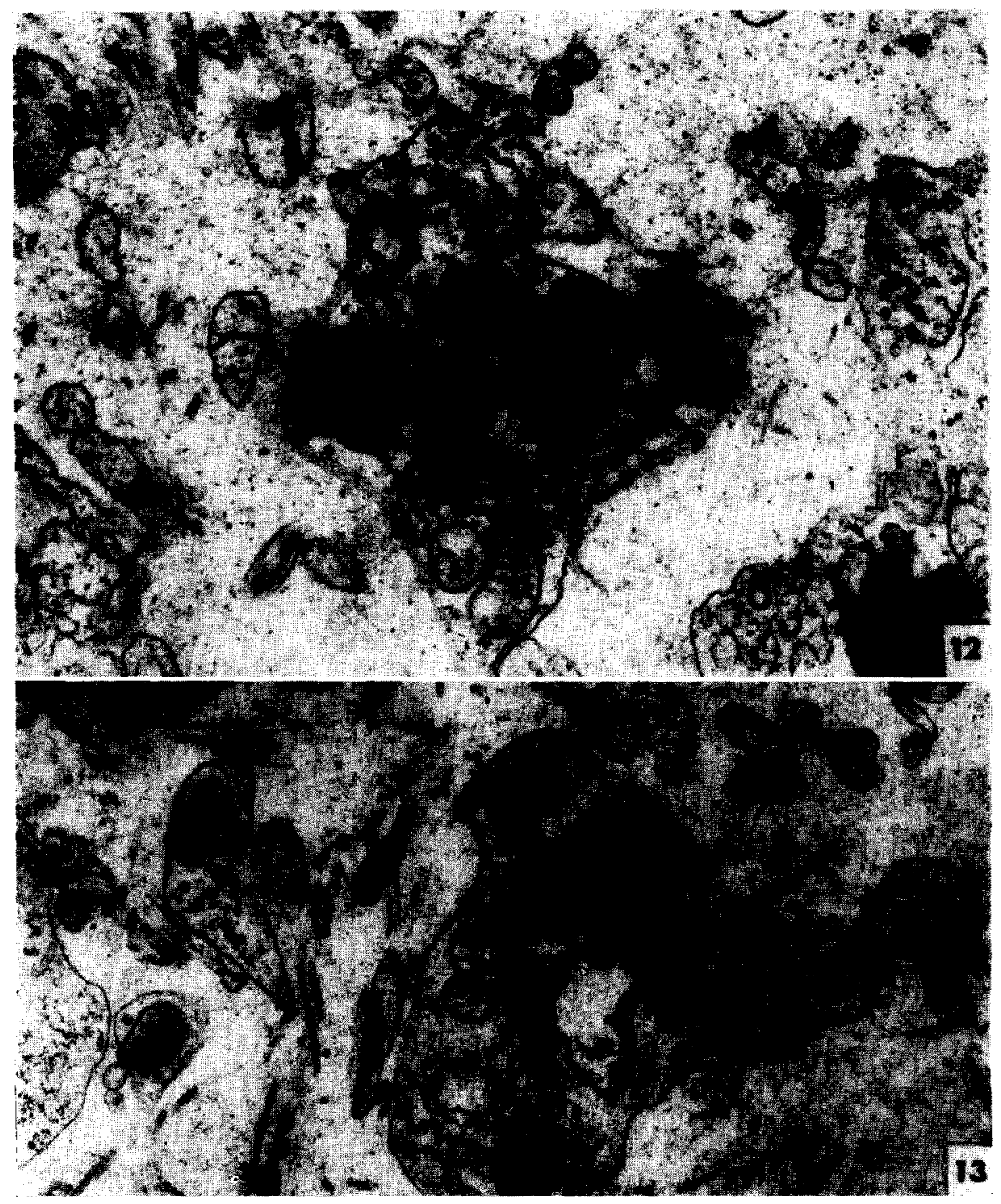

FIGS. 12 AND 13. Pieces of peripheral cytoplasmic processes of fibroblast from rats injected with actinomycin $\mathrm{D}, 10$ days previously. In addition to some of these cytoplasmic changes depicted previously, a fair number of lipid droplets are observed in these cells. Approximately $\times 8060$. 
FIBROBLAST AND ACTINOMYCIN D

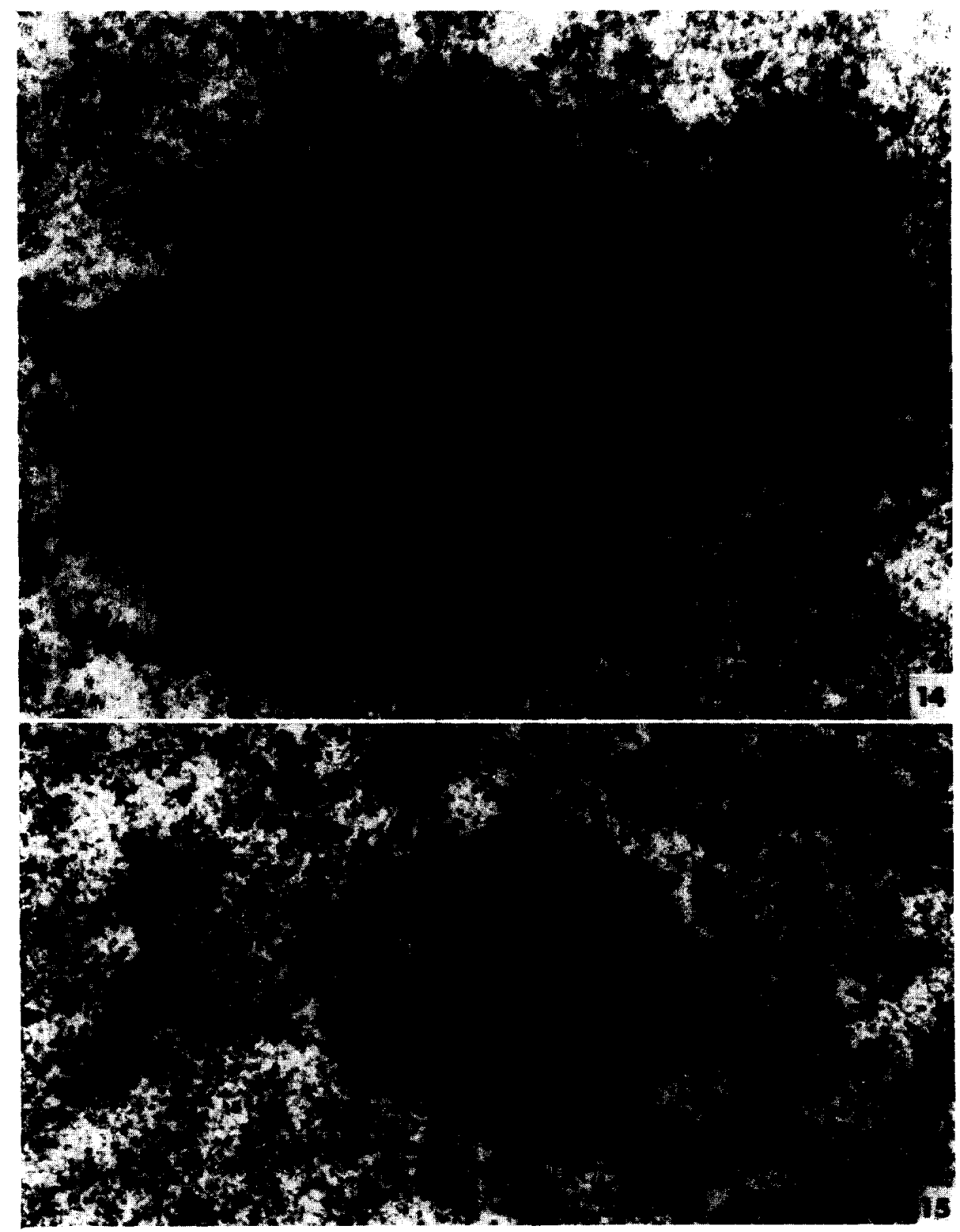

Fig. 14. A nucleolus of a fibroblast from a control animal. Various morphological components of the nucleolus previously described can be depicted with clarity and numerous $150 \AA$-granules surround the homogeneous regions of the organelles. Approximately $\times 71,680$.

FIG. 15. A nucleolus of a fibroblast from an animal injected with actinumycin D, 7 days previously. Notice the relatively small size of the nucleolus and the disappearance of $150 \AA$-granules. Approximately $\times 62,850$. 